\title{
Possibilities of Using Remote Sensing in Archaeological Research in Bengal Delta in Bangladesh - A Human-Influenced Alluvial Terrain
}

\author{
Khorshed Alam AKM* \\ Formerly Geological Survey of Bangladesh
}

Submission: October 21, 2018; Published: December 20, 2018

*Corresponding author: Khorshed Alam AKM, “Shapla Garden”, 60/G North Dhanmondi, Dhaka 1205, Bangladesh

\begin{abstract}
Bangladesh, an alluvial country lying in an active tectonic region of the world, has a huge population and rich archaeological heritage. The fluvio-deltaic landforms of the country are continually changing due to geologic processes, natural hazards and anthropogenic activities. In such an actively changing condition it is difficult to preserve and to detect the archaeological sites. From archaeological point of view, it is also important to understand the relationship between the human settlements and migration, and the changing landforms. Remote Sensing can help both to explore the archaeological sites and to understand the relationship. Advantages like multi-spectral, multi-resolution and multi-temporal capabilities of remote sensing can be taken to solve special problems. Over the last few decades, remote sensing technology has tremendously developed, and area of application has also widened. Possibilities of use of this technique in the context of Bengal Delta in Bangladesh have been evaluated. Use of remote sensing data would increase the efficiency of archaeological discovery/research through saving time and money in a country having intense anthropogenic activity and continuously changing alluvial landforms.
\end{abstract}

Keywords: Remote Sensing; Archaeology; Alluvial Terrain; Anthropogenic Influence; Geoarchaeology; Bengal Delta; Bangladesh

Abbrevations: AMSL: Above Mean Sea Level; DEM: Digital Elevation Model; UAVs: Unmanned Aerial Vehicles; VHR: Very High Resolution; NIR: Near Infrared Red; GPR: Ground Penetrating Radar; MIR: Mid Infrared; TIR: Thermal Infrared; MS: Multi-Spectral

\section{Introduction}

In archaeology, research design involves selecting a region or site for survey, excavation and recovering data. Excavation is costly and is increasingly seen as last resort [1]. Remote sensing gives a synoptic view of the surveying sites, frequently, and at low cost, of often inaccessible areas, saving time and money. In favourable circumstances and with the efficiency of the interpreter, it can record details of the buried sites revealed by discolouration in the overlying soil or vegetation [2]. Threedimensional effect from the terrain can be achieved with the help of stereo pair aerial photographs. However, optimum utilization of remote sensing technology depends on clear understanding of the interaction among electromagnetic spectrum, atmosphere and terrain characteristics.

Bangladesh is covered with Tertiary folded sedimentary rocks $(12 \%)$, Pleistocene soil (8\%) and Holocene alluvial sediments (80\%). Moreover, it is in a tectonically active region of the world. These sediments, consisting mainly of unconsolidated sand, silt and clay in varying amounts, come from different geological environments and deposit in different geomorphological conditions. Besides these, the country is tackling anthropogenic activities where population become double within 40 years.
Climate is another important factor, which has relevance in shaping of the earth's surface because the processes that act upon the surface material are different in different climate zones [3]. Bangladesh enjoys a tropical monsoon climate [4]. Mean annual rainfall is $1250 \mathrm{~mm}$ in the centre-west, more than $2500 \mathrm{~mm}$ in the north-west and near the coast and exceeds $5000 \mathrm{~mm}$ in the north-east [5]. Mean temperature is about 25 ${ }^{\circ} \mathrm{C}$, and that ranges from $18{ }^{\circ} \mathrm{C}$ to $30{ }^{\circ} \mathrm{C}$ in winter and summer respectively. Wind is generally light, but it goes $50-100 \mathrm{~km} / \mathrm{hr}$ or more during pre-monsoon or cyclones. Evaporation is about 50 $75,100-175$ and $100-125 \mathrm{~mm} /$ month in winter, pre-monsoon and monsoon respectively.

Application of remote sensing in Bangladesh geology started during the middle of 1950s [6]. For practical reasons aerial photographs were used for geological mapping till the availability of satellite remote sensing data, which is continuing. Scientists of the country have been working with aerial photography, Landsat (MSS, TM, ETM+), SPOT, IRS, Radarsat, JERS-1, Lidar, CORONA satellite photograph, RapidEye, Pleiades data in different fields of geology [6]. Other fields of application include forestry, soil, environment, agriculture, water resources, 
natural hazards etc. Application in archaeology remains only within geoarchaeological studies.

In the following paragraphs archaeological heritage [79] and fundamentals of geology of the country have briefly been described. At the later part basics of remote sensing with information extraction procedures and requirements for archaeological research are discussed. Current status of remote sensing application in archaeology in the country and elsewhere has been reviewed. Results of few such applications and possibilities of future applications of remote sensing in the archaeological research in Bangladesh are discussed.

\section{Archaeological Heritage of Bangladesh}

Majority of the landforms of Bangladesh are originated from fluvial and deltaic processes forming the largest delta of the world. Quaternary sediments and soils cover about 90\% area of the country. Among the four favoured general environments for human habitation two -- alluvial and coastal environments [10] exist in Bangladesh. It has huge networks of large and small rivers with their fertile floodplain replenished with sediments and nutrients during annual floods. The floodplain provides food, drinking water and water for irrigation; rivers provide communication networks, sediments are sources of important raw material, gravels are used for constructions. The country has a vast coastal plain that also favours for food, communication for trade and others. All these favourable conditions attracted humans since long. This vast alluvial land holds the settlements having its own people and as well as people from different countries and nations having different ethnicity, religion, race, language and culture from pre-historic age till to date.

However, during the second half of the first millennium, ancient Bengal including present-day Bangladesh, West Bengal and parts of Assam and Bihar of India were roughly divided into several political divisions which consisted of Pundra or Varendra (North Bengal), Rahr (West Bengal and adjacent parts of Bihar), Kamrupa or Anga (Assam), Vanga or Harikel (Southern Bengal) and Samatata (South-eastern and eastern Bengal). However, Dinajpur, Rajshahi and Bogra region (Figure 1) of Bangladesh have signs of the Early Historic settlement that can be assigned to the $3^{\text {rd }}$ century BC [7], although the history of the period between the fall of the Mauryan Empire (2nd century BC) and the rise of the Gupta rule ( $4^{\text {th }}$ century AD) is unclear. The Pal dynasty ruled Bengal from $~ 781$ to 1124 AD of which Somapura Mahavihara is one of the important evidences. Later Sen Empire ruled during 1158 - 1205 AD. Muslim era started in 1204, Lakhnauti in Dinajpur was conquered. The empire, centring Lakhnauti, was supposedly stretched to the Padma/Ganges River in the south, Rangpur and Dinajpur (Devkot) in the north, Bihar (India) in the west, and the rivers of Tista, Brahmaputra and Karatoya in the east. Later in $1338 \mathrm{AD}$ independent sultanate was established in Bengal which remained for 200 years. Afterwards Delhi-based Mughal rule started that continued till the death of Aurangzeb in 1707 and afterwards became weak gradually. Bengal was ruled by independent rulers till 1757 and British ruled from 1757 to
1947 followed by Pakistani regime of 1947-1971. Afterwards Bangladesh emerged as an independent nation in 1971.

\section{Prehistoric Settlements (Neolithic Settlements)}

Archaeologists identified several potential paleolithic, mesolithic and neolothic sites in Bangladesh. All the reported locations of pre-historic archaeological records are confined to the Pleistocene lateritic terraces of Lalmai Hills of Cumilla and uplands of Narshingdi, Sylhet, Habiganj, Rangamati and Chattagram districts [9]. Discovered materials are pre-historic artifacts made mainly from silicified or fossil wood or fossil. These areas lie mostly in the north-eastern and eastern parts of the country that are geologically occupied by hills of Tertiary sedimentary rocks, except those of Cumilla and Narshingdi which are uplifted terraces of Pleistocene time (Figure 1).

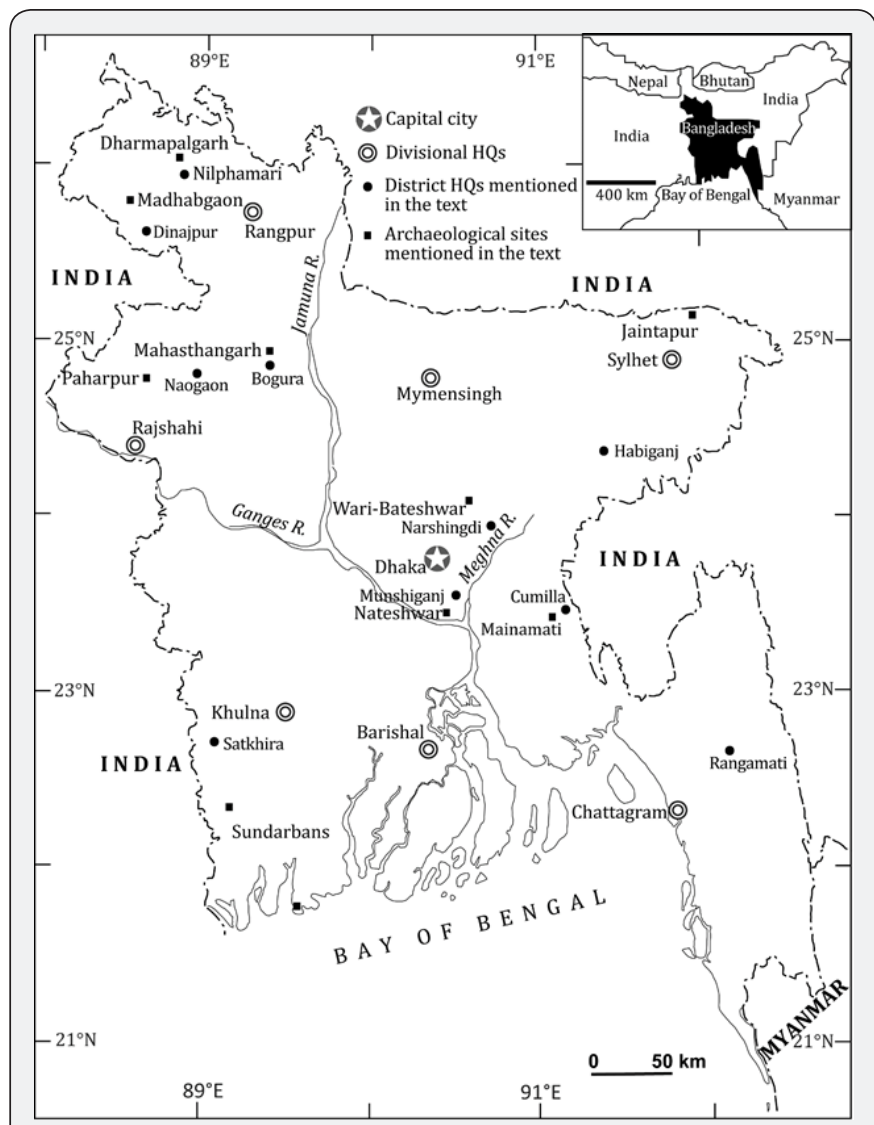

Figure 1: Map of Bangladesh showing the archaeological sites/ places cited in the text.

\section{Chalcolithic Settlements}

Chalcolithic cultures are evidenced by Black-and-Red ware and pit-dwelling were discovered in Wari-Bateshwar area of Narshingdi district, area lies on the uplifted terrace of Pleistocene. Hearths and wells have also been discovered there. The Iron Age began in the middle of the Chalcolithic age (1200 BC) and lasted until the onset of the early historic period (400 BC). In Bangladesh, traces of the settlements belonging to the later part of the Iron Age have been found in Mahasthangarh of Bogura district (Figure 1). Though the iron tools were made in the primitive techniques from $1200 \mathrm{BC}$ to $700 \mathrm{BC}$, advanced 
techniques were adopted after 700 BC onwards. Exactly from this period, the human settlements in Bengal started undergoing qualitative changes along with the other parts of the subcontinent. The use of iron played a significant role in the economic, social, cultural and political life. It is consistent to mention here that the Megalithic culture is a specialized form of the Iron Age [7].

\section{Megalithic Culture}

The remains of Megalithic culture are found in various countries of Europe, Africa and Asia. In the Indian subcontinent megalithic culture started in Neolithic period, however, it flourished during the Iron Age. In Bangladesh, evidences of megalithic culture are found in Jaintapur (Figure 1) of Sylhet district, which includes upright stone (menhir) and slab stone (dolmen) horizontally resting on several stone posts [9]. This area lies in the north-eastern hilly region of the country and occupied by younger Tertiary sedimentary rocks. Brief descriptions of few important archaeological sites/places of Bangladesh are given below.

\section{Important Historical-Period Settlements}

Wari-Bateshwar, Narshingdi: The Wari-Bateshwar (Figure 1) region in Narshingdi, Bangladesh is the site of an ancient fort city dating back to 450 BCE. The 2500-year-old ruins lie near the Old Brahmaputra River. The sites are located on the flat-topped surface of the Madhupur Tract [11] underlain by Madhupur clay residuum [12]. Wari-Bateshwar is the rich, well planned, ancient emporium (a commercial city) "Sounagora”, mentioned by Greek geographer, astronomer, mathematician Ptolemy in his book Geographia [13].

Wari-Bateshwar, in $600 \mathrm{~m} \mathrm{X} 600 \mathrm{~m}$ enclosure with four mud ramparts, is called a fort-city or urban centre. So far 50 archaeological sites have been discovered in and around WariBateshwar. From pattern of archaeological sites, discovered artifacts and sandwich glass bead, it is evident that the settlement was developed in flood free zone and it was affluent trade centre and its inhabitants depended on agriculture [14]. The discovery of Janapada coins places Wari-Bateshwar back to the Sodosha Maha Janapada (ca. 600-400 BC) kingdom of Indian subcontinent. In recent archaeological excavation evidence of human settlement has been discovered which bears the character of Chalcolithic culture, the most important discovery of this culture is black and red ware and evidence of pitdwelling. Several neolithic tools have been discovered from this region, though all the tools are chance finds and no prehistoric settlement has yet been identified. The discovery of prehistoric tools indicates the prehistoric settlement in the region which is waiting to be explored [14].

Mahasthangarh, Bogura: Mahasthangarh is one of the oldest archaeological sites of Bangladesh, lies on the right bank of the Karatoya River, about $12 \mathrm{~km}$ north of Bogura town (Figure 1). The spectacular site is an imposing landmark in the area, having a fortified, oblong enclosure measuring $1524 \mathrm{~m} \times 1370 \mathrm{~m}$ with an average height of $5 \mathrm{~m}$ from the surrounding areas. Like the Wari-Bateshwar area, similar settlement patterns are evident at Mahasthangarh (Pundranagar) [14]. The elevation of the Mahasthangarh ranges from $15 \mathrm{~m}$ to $25 \mathrm{~m}$ and is at a higher in elevation than the surrounding flat plains and relatively flood free. The site lies on the eastern part of the Barind tract covered by Pleistocene Barind clay residuum [12] and sub-Recent sediments borne by Bangali and Karatoya rivers. KaratoyaBangali meander floodplain has a complex landscape containing sediments of Holocene age. Other important rivers that drain the tract are the Atrai and Karatoya rivers discharging into the Jamuna River to the southeast, and a few small and monsoon-fed seasonal rivers e.g. Ichamati, Bangali and Nagar. Many swampy areas, locally known as beels are also found around the area [14].

Somapura Mahavihara, Paharpur, Naogaon: Somapura Mahavihara was one of the most famous Buddhist monastic institutions of ancient Bengal. The excavated monastic complex at Paharpur (Figures $1 \& 2$ ) has been identified with the Somapura Mahavihara built by the second Pala king Dharmapala (c 781-821 AD). The monastery flourished until the $11^{\text {th }}$ century AD. The monastery was repaired and renovated during the reign of Mahipala (c 995-1043 AD), and it is recorded in the Tibetan work, Pag Sam Jon Zang that the same king used to visit Somapura Vihara to offer his homage to it. Somapura Mahavihara gradually declined and was finally abandoned during the $13^{\text {th }}$ century, when the area came under Muslim occupation [14]. This site has been included to the UNESCO declared World Heritage.

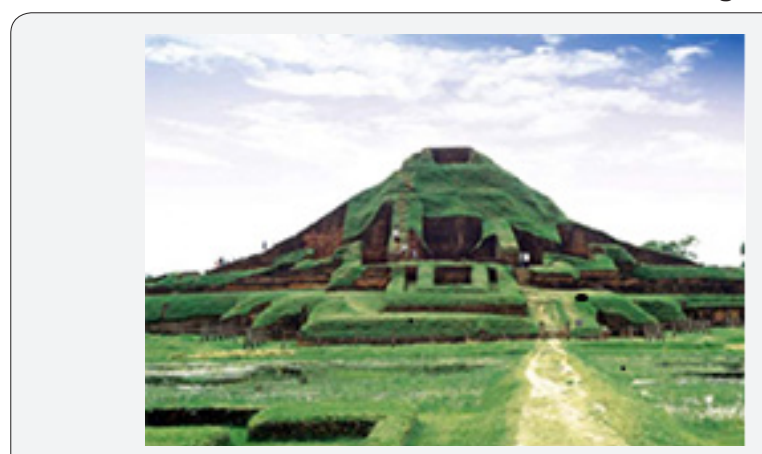

Figure 2: Somapura Mahavihara, Paharpur, Naogaon, Bangladesh (Taken from [14]).

Mainamati, Cumilla: Mainamati archaeological site, dotted with more than 50 ancient Buddhist settlements of the 8th to 12th century AD [14], is located on the Lalmai Hills (Figure 1). Lalmai Hills, lying west of the Cumilla town, is a $19 \mathrm{~km}$ long, north-south trending hilly terrain and has an average elevation of $30.50 \mathrm{~m}$ above mean sea level (AMSL). It is gently sloping to the east; the western flank is cliff-like, overlooking the Chandina deltaic plain to the west [15]. The elevation of the plain is about 6.7-9.7 $\mathrm{m}$ AMSL. The area is drained by three major rivers -- the Gumti, the Dakatia, and the Little Feni and numerous rain-fed channels. The Lalmai hill comprises the Dupi Tila Formation of the Plio-Pleistocene age, blanketed by Madhupur clay residuum of Pleistocene time [12]. Alam [16] gave the impression of Recent uplift in the area based on drainage anomaly, nature of 
the western scarp, differential soil development, rapid filling of closed depressions at the toe etc.

Nateshwar, Munshiganj: Several archaeological evidences of a Buddhist city older than a thousand years have been discovered at Nateshwar (Figure 1) of Tongibari Upazila in Munshiganj district. These include an entrance and walkway, prayer hall, mortar floor, octagonal stupas, pot shreds, baked clay materials and burnt bricks. The aesthetic of these stupas is unique in architectural style. More than 5,000 square meters were unearthed at Nateshwar and a series of significant results were achieved by this time [17]. C14 dating shows that there were two phases of human habitat in the area - first from 780 to $950 \mathrm{AD}$ and the second from 950 to $1223 \mathrm{AD}$ [13].

Coastal Area (Sundarbans): Recently an archaeological site (Figure 1) has been discovered in the Sundarbans mangrove forest in the south-western coastal region of Bangladesh. So far five spots have been identified there. An estimated age of this archaeological site goes back to about one thousand five hundred years. The sites are scattered on the coast to the Bay of Bengal and on the river banks of the area. From the first impression it is thought the site was developed for salt industry and trade centres, but there were permanent human settlements. These sites are in Shyamnagar of Satkhira and at Katka part of Khulna districts [18].

Another archaeological site (Figure 1) was discovered few years ago in the coastal Sundarbans, a huge UNESCO-protected mangrove forest. Discovery includes submerged salt-producing kilns; built just above the winterly spring high-tide level of time but their bases are currently located $\sim 155 \mathrm{~cm}$ below the corresponding modern level. Age of the site was calculated from OSL dating and supported by C14 dating to 300 yr ago [19].

\section{Regional Tectonic Setting, Geomorphology and Geol- ogy of Bangladesh}

\section{Regional Tectonic Setting}

Bangladesh constitutes the eastern continuation of the central broad Indo-Gangetic plains of India between the Peninsular (shield) area to the south and the extra-Peninsular (Himalayan mountains) region to the north and northeast. At the eastern part of the plain the Bengal Basin is located, having varied tectonic history. The Basin consists of major part of Bangladesh and small portion of West Bengal of India. Bengal Basin lies north of the Bengal Deep-Sea Fan and is bounded on the north by the Shillong Plateau, in the west by shield and in the east by Indo-Burma Folded belt. The Dauki Fault Zone forms an active major east-west tectonic element [20] that separates the Shillong Plateau from the subsiding Surma basin of the Bengal Basin [21]. Tectonically, Bangladesh lies on the Indian plate that is gradually closing to Eurasian plate to the north at a rate of approximately 36-45 mm/year [22] and its eastern margin is bounded by Indo-Burma Folded Belt where an atypical continent-continent subduction is going on [23], the Burmese plate (Figure 3 ) is moving westward at the rate of $20 \mathrm{~mm} /$ year.

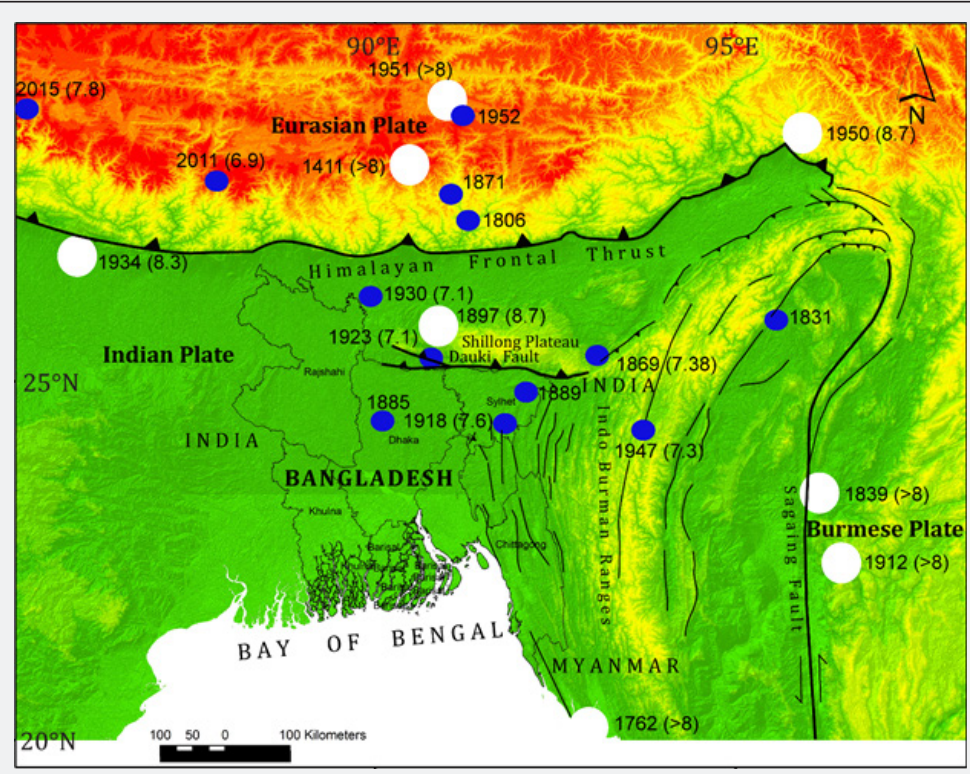

Figure 3: Regional tectonic setting of Bangladesh. Solid circles are epicenters of earthquakes.

Based on the results of geophysical surveys, geological mapping and borelog data Bangladesh part of the Bengal Basin could be divided into two major divisions 1) the Rangpur Platform (also known as 'Indian platform' or 'Stable shelf') and 2) the Bengal Foredeep [4,24]. The Rangpur Platform is further subdivided into three zones (i) the elevated part of the basement complexes the 'Rangpur Saddle', (ii) the northern slope of the saddle the 'Himalayan Foredeep' and (iii) the southern slope of the saddle 'Bogra Shelf'. The Hinge Zone, about $25 \mathrm{~km}$ wide with NE-SW trending, separates the Bogra Shelf and the Bengal Foredeep, the latter is a region of great subsidence of the crust, accumulating thick sediments. The Foredeep has been 
subdivided into two major tectonic zones, (i) the deep basinal unfolded or gently folded 'Platform Flank' and (ii) the 'Folded Flank' comprising hilly regions of the Chittagong Hill Tracts, Chittagong and Sylhet districts.

\section{Geomorphology and Geology}

Geomorphologically, major part of the country is occupied by one of the largest deltas of the world formed by the GangesBrahmaputra-Meghna river system originated from the uplift of the Himalayas. The delta prograded south accompanied by rapid subsidence in the basin resulting deposition of huge thickness of deltaic to fluvio-deltaic sediments. The delta building process is continuing into the present Bay of Bengal and broad fluvial front of the major system gradually follows it from behind. Major landforms of the country are being produced by fluvial, tidal and estuarine processes resulting floodplains of Ganges-Brahmaputra-Meghna rivers, deltaic and coastal plains, piedmont i.e. alluvial fans, and estuarine plains. Apart from these, there are three tracts viz. Barind Tract, Madhupur Tract and Lalmai Hills [4]. The north-eastern and eastern parts of the country are occupied by hills (Figure 4).

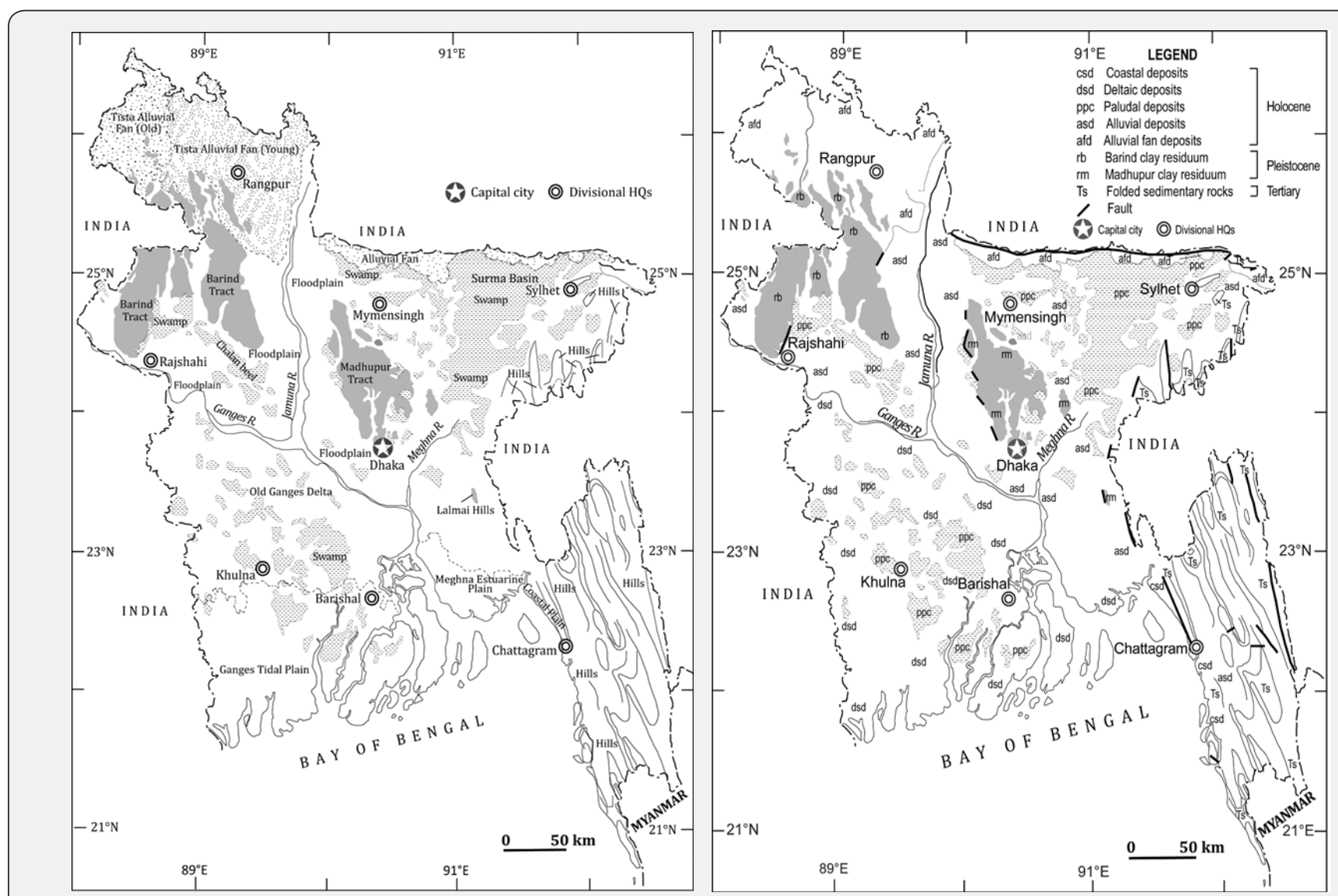

Figure 4: Simplified and generalized geomorphological map (left) and generalized geological map (right) of Bangladesh (Information taken from [12,34] for geomorphological map; taken and simplified from [12] for geological map).

A large alluvial fan, known as Tista alluvial fan, has been developed in the north-western part of the country, rich in archaeological heritage. The alluvial fan is divided into western as old and eastern as young fans. Besides these, a series of small alluvial fans have been developed at the south of the Shillong Plateau and affected by neotectonic activities [25], and at the base of the eastern hills a narrow piedmont plain has been developed. The floodplains and delta are studded all over with clusters of swamps (depressions) locally known as haor or bil/ beel [26]. The most important cluster is Sylhet trough or Surma basin in the north-eastern part of the country. It is a tectonically active and subsiding basin [27]. Another large swamp lies in the north of the Ganges River, known as Chalan beel. Other swamps exist in the central delta.
The coastal region of the country is divided into old Ganges delta plain in the west, Meghna estuarine plain in the middle and Chittagong coastal plain in the east. Each of these units has their own morphological and sedimentary characteristics. Among other factors, active tectonic nature of Bengal basin, occupying major part of the country, results in a highly complex geomorphology [28]. Several studies show that many of the changes in river courses, deposition of sediments and landform development are affected by tectonics operating in the region. Result of the on-going tectonic movements at the Himalayan front is development of alluvial fans developed at the south [29]. Part of one of these vast fans lies in Bangladesh, the Tista fan. Half of the country is lower than elevation of $12.5 \mathrm{~m}$ above sea level. The elevation of hilly areas, occupy the eastern and north- 
eastern parts, lies between 70 and $1000 \mathrm{~m}$. The alluvial plains have the elevation from about $90 \mathrm{~m}$ in the north-western part of the country to $0 \mathrm{~m}$ along the coastal part. Among the uplifted tracts, the maximum elevation, about $40 \mathrm{~m}$, was observed in the Barind Tract [30], however, Reimann [4] found about $45 \mathrm{~m}$ above mean sea level.

Geologically, $80 \%$ of the surface and near surface of the country is formed of Holocene deposits [12]. The Holocene deposits, consisting of unconsolidated sand, silt and clay of varying amounts, are the products of piedmont, alluvial, fluvial, deltaic or coastal processes. Eight percent area is covered with Pleistocene clay residuum in the three uplifted terraces (Figure 4). These three tracts are underlain by red to brown coloured oxidized soil. Alam [31] found foundry, chimney with slag and laterite deposits etc. on the Madhupur Tract, and he thought that those are products of iron manufacture in the early days of the history of Bangladesh. The Tertiary sedimentary rocks; consisting mainly of sandstone, siltstone, shale and clay; cover $12 \%$. The oldest exposed rock is the Tura Sandstone of Paleocene age but older rocks like Mesozoic, Paleozoic and Precambrian Basement have been encountered in the drill holes in the northwestern part. Through a long geological time (Permian to Recent) the basement of Bengal Basin, below a thick sedimentary cover, has been severely faulted and fractured which are covered under Holocene surficial deposits.

\section{Factors Controlling Changes in Landforms in the Con- text of Bangladesh}

Fluvial environment is dynamic and constantly changing. Constant deposition of sediments and erosion; slow lateral migration and avulsion of channels due to usual geomorphological processes and tectonic process contribute to the changes in the physical appearance of floodplains. But the common factors that control the supply and deposition of sediments are climate change over time, active tectonics, sea level changes, and change in land use due to anthropogenic activities.

The coastal environment, the most dynamic of environment on the earth, was one of the earliest choices for human habitation. Changes are brought about by interplay between marine and terrestrial processes, tectonic activities resulting uplift and subsidence, climate effect and meteorological events like storms. Bangladesh coastal zone frequently experiences cyclones, in many cases with surges. Syvitski [32] give an estimated stormsurge area on the delta of Bangladesh to be 10,500 sq. $\mathrm{km}$.

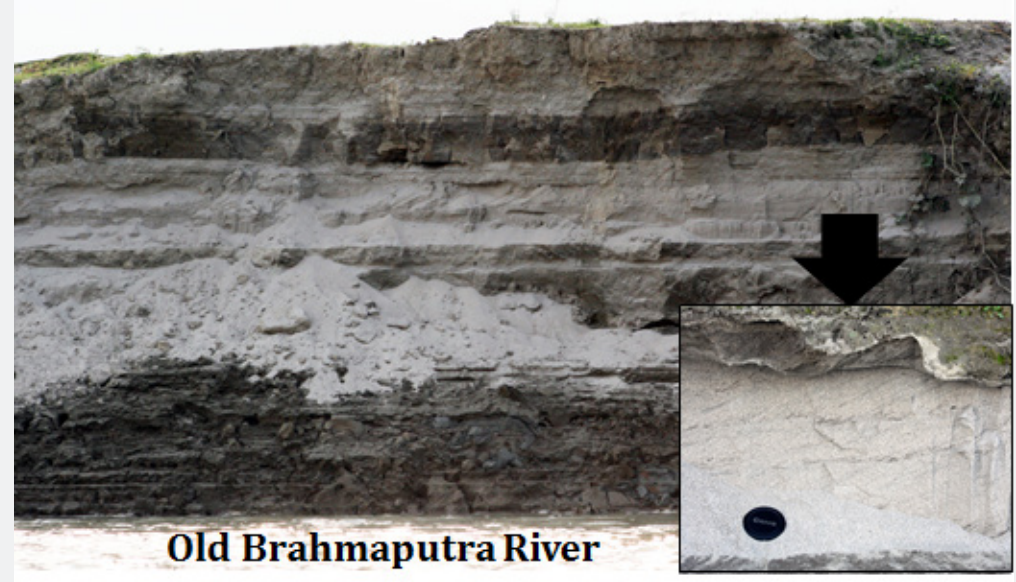

Figure 5: Thick sedimentation during high flood event. Photograph taken from the Old Brahmaputra River Floodplain, Central Bangladesh

\section{High Sedimentation Rate}

The Ganges, Jamuna-Brahmaputra and Tista rivers carry huge amount of sediment whereas the Meghna River carries much less amount. In an estimate, Kuehl [33] showed the total amount to be of one billion ton of which $30 \%$ are deposited on floodplains. Most of these sediments are carried during the rainy season. Sometimes episodic floods bring enormous amount of sediments that suddenly bury the depositional surface thickly (Figure 5).

\section{Geomorphic and Neotectonics Processes}

Usual fluvio-deltaic processes are continually shaping this largest delta of the world. However, geomorphology of the delta becomes complex because of ongoing tectonics. Many workers [25,30,34-41] show the uplift of the Madhupur Tract, a Pleistocene tract composed of oxidized soil and stands above the active floodplain. with distinct scarp along the western side, hanging and beheaded valleys, incised drainage on the tract and flow direction indicating tilting in the east, west and south-west. Islam [11] detected evidences from the Madhupur tract in central Bangladesh that indicate Holocene tectonics. Bakr [15] described in detail the relationship of archaeological sites of $8-10^{\text {th }}$ century and landscape, how the uplift of the Early Recent Chandina Deltaic Plain including shifting of river courses badly affected the environment of the area which lies in the eastern part of the present-day Bangladesh. Alam \& Alam \& 
Islam [21,25] identified several evidences in the areas south of Shillong Plateau indicating recent tectonics.

Shifting of the Tista River from southerly direction to southeast direction occurred in 1787 and that of the Old Brahmaputra River from east of Madhupur tract to west of the tract taking present Jamuna channel occurred sometimes between 1765 and 1830. These changes probably occurred after the major flood of 1787 [34]. As the two large rivers came to the Jamuna valley from opposites sides, it is logical to believe that ongoing tectonics is responsible for these changes. The Jamuna valley follows the Jamuna fault [42] and another significant point is occurrence of two 7.0 magnitude earthquakes within the valley in 50 years. Besides these, many examples of shifting of rivers courses can be cited although not all of them are due to tectonic effect.

\section{Natural Hazards}

Flood occurs every year submerging floodplains of Bangladesh to which people are adapted, but in some years, flood turns abnormal submergence. The later causes damage to property and crops, communications, disrupts economic activity and endangers lives [34]. Floods in Bangladesh are normally associated with annual monsoon rainfall into the Ganges-Brahmaputra-Meghna basin. Monsoon rain and high river flows across the country's boundaries are the dominant cause, but other factors such as flat and lowlying topography, bank erosion, siltation, earthquake, storm surge, neotectonics activity, man-made-structures also contribute to inundation and sedimentation. In the living memory, the country experienced worst flooding in 1974, 1987, 1988, 1998 and 2004. Sometimes one flood event may carry enormous amounts of sediments, capable of burying the surface deeply (Figure 5).

The Bangladesh coast experienced 149 cyclones between 1891 and 1998 [43]. The storm surge height attained 10.6m in 1970 cyclone, but its range was 3.0-6.7 during 1960-2007 [43]. The cyclones with storm surges carry enormous sediments from the sea and deposit on the coastal zone. Recent evidence shows how much sediments carried by cyclone Sidr of 2007 that buried the roots of mangrove plants under about $1 \mathrm{~m}$ depth in the Kuakata coast (Figure 6), SW Bangladesh.
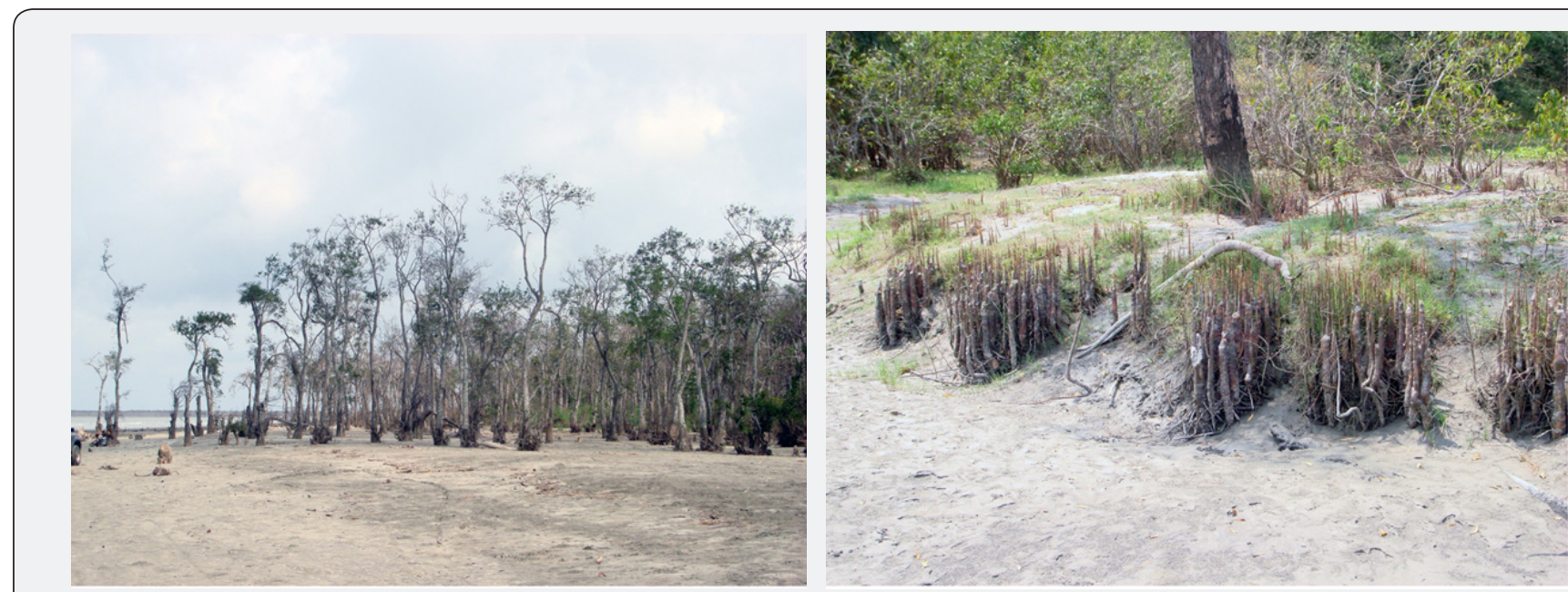

Figure 6: About $1 \mathrm{~m}$ thick sediment accumulation during cyclone Sidr 2007 in the south-western coast of Bangladesh that buried roots of mangrove trees.

This region of the world was shaken by 7.0 or greater magnitude earthquakes during the last two hundred and fifty years e.g. 1762, 1885, 1897, 1918, 1930, 1934, 1950 [25]. These earthquakes had significant impacts on the geology and geomorphology, and on the lives, properties and infrastructures as well. During first half of this decade the country was shaken by 6.9 Sikkim (2011) and 7.8 Nepal (2015) earthquakes, although there was no damage, but Alam [44] and Alam \& Ahsan [45] clearly showed the relationship between earthquake shaking and response of geologic materials i.e. local soil condition. Even low magnitude earthquakes, in some instances, were responsible for morphological change, shifting of streams, generation of earth fissures and liquefaction $[25,46]$ causing changes in landform. The above evidences show that natural hazards were capable enough in changing landforms in the past like the present.

\section{Subsidence}

The delta is suffering from subsidence due to usual geological processes and tectonic reasons as well. Alam [47] outlined that the Ganges-Brahmaputra delta is subsiding at a rate of $2-4 \mathrm{~mm} /$ year. Higgins [48] show a subsidence rate of 0 to $>10 \mathrm{~mm} / \mathrm{yr}$ in Dhaka. Hanebuth [19] gave a subsidence rate of the outer delta to be $5.2 \pm 1.2 \mathrm{~mm} / \mathrm{yr}$. From the above results it is clear now that different parts of the delta subside at different rates. The subsidence causes changes on geomorphology.

\section{Anthropogenic Activities}

Population of the country increased from 75 million in 1971 to about 150 million in 2011 [49] with a density of population of $976 / \mathrm{sq} \mathrm{km}$ in 2011. Due to the rapid increase of population land covers are being continually and rapidly changed for 


\section{Global Journal of Archaeology \& Anthropology}

urbanization (Figures $7 \&$ 8), cultivation, construction of roads and industries. This is happening throughout the country. Landfills for land development for construction and dumping municipal wastes, digging for soil and sand collection, cutting for levelling lands and hills are common practice, lead to landform changes.

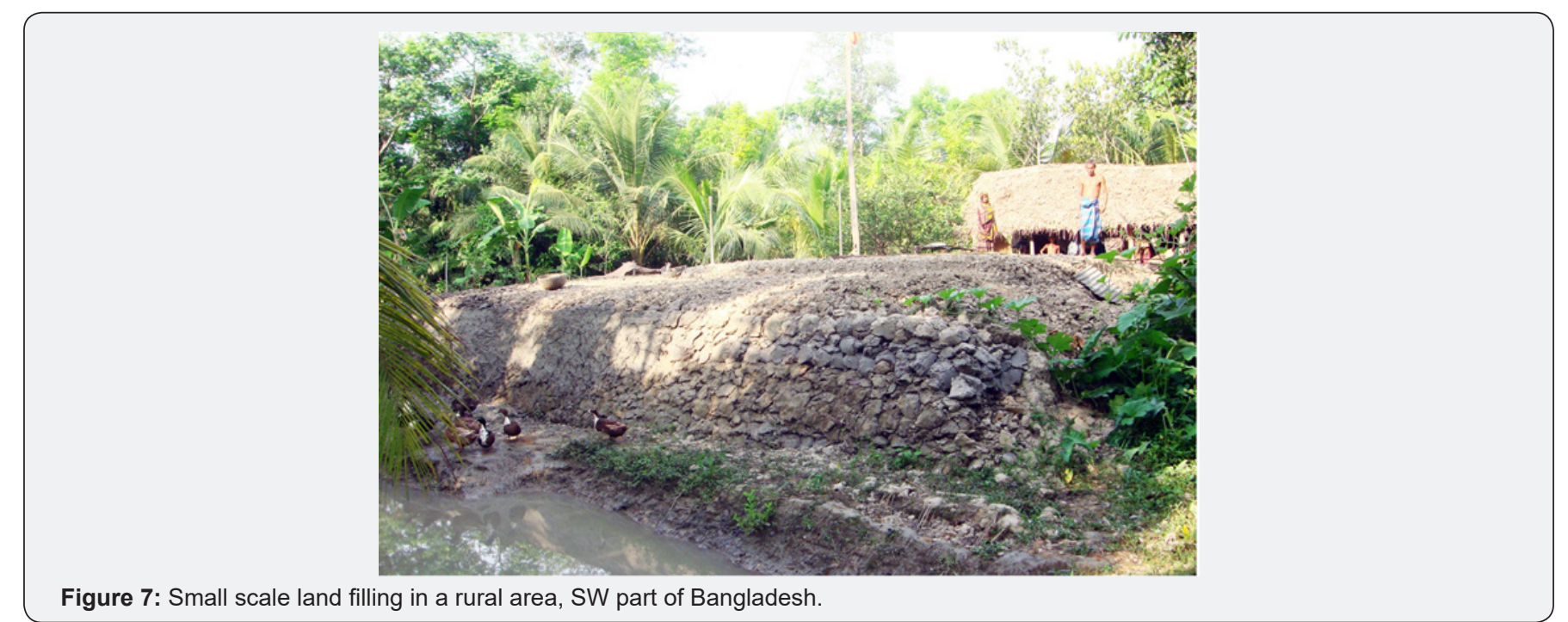

Figure 7: Small scale land filling in a rural area, SW part of Bangladesh.

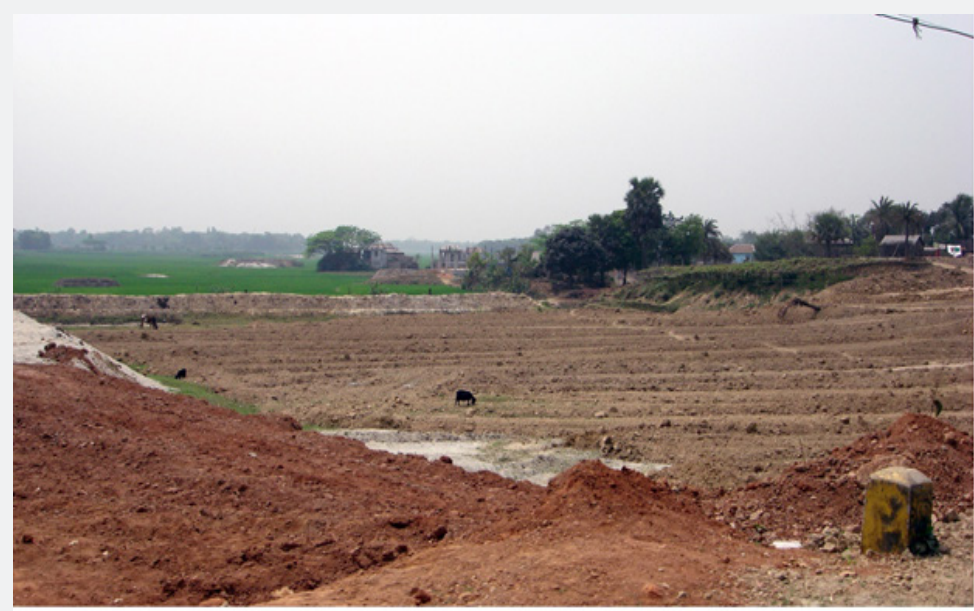

Figure 8: Large scale filling and land development in an urban area near Dhaka, Bangladesh.

\section{Climate change}

It is now widely believed that Global warming, ozone layer depletion in the atmosphere and rain forest destruction are some of the crucial problems. These changes would affect the environment in different ways. Since it is a global phenomenon Bangladesh cannot escape from it.

Thus, retreats of sea, subsidence, natural hazards, anthropogenic influence are the causes of the ruins of many of the archaeological sites/places in the delta.

\section{Basics of Remote Sensing}

\section{Introduction}

Broadly, remote sensing is defined as the acquisition of information about the surface of the land and ocean, and the atmosphere, by air- or space-borne sensors. It includes both passive and active sensors, receiving reflected and emitted electromagnetic radiation respectively. Remote sensing of earth has come a long way from nineteenth century aerial photography, but now it means satellite remote sensing, started with the launch of Landsat-1 in 1972 for civilian applications. Operation of these varies from low altitude Unmanned Aerial Vehicles (UAVs) to high altitude satellites orbiting the Earth. The electromagnetic radiation includes a very wide range of energy, from X-rays through visible light to radio waves. However, only a portion of the huge electromagnetic spectrum is actually used for remote sensing. This paper mainly deals with the satellite remote sensing. Over the time, the field of satellite remote sensing has passed through new developments e.g. higher spatial resolution optical and radar systems, hyperspectral sensors having the capability of generation of digital elevation model (DEM).

\section{Information Extraction Process}

Successful use of remote sensing data depends on the ability of extraction of meaningful information from the imagery, where both visual image interpretation done manually and digital image 
processing using computers. However, both techniques have their respective advantages and disadvantages. Knowledge of the specific geographic region depicted on an image can be equally significant because every locality has unique characteristics that influence the patterns recorded on an image [50].

\section{Visual Image Interpretation}

Much interpretation and identification of targets is done manually or visually. This requires recognizing targets, which is the key to interpretation and information extraction. Observing the differences between targets and their backgrounds involves comparing different targets based on any, or all, of the visual elements of tone (or hue), shape, size, pattern, texture, shadow, and association (site and situation) by human knowledge and experience. If a two-dimensional image can be viewed stereoscopically to simulate the third dimension of height, visual interpretation will be much easier. Aerial photograph gives such opportunity. Radar response is controlled by wavelength, incidence angle, polarization, and surface roughness and dieelectric constant of the soil, depends on moisture content. For these Radar images have certain characteristics that are fundamentally different from optical and thermal images [51], include speckle, texture and geometry. During image interpretations this should be borne in mind.

Tone (or hue) refers to relative brightness or colour of objects on an image. To the interpreter it appears as relative lightness or darkness in the region under study. Shape refers to the general form, configuration, or outline of individual objects. Size of objects on images must be considered in the context of the image scale. Pattern refers to the arrangement of individual objects into distinctive recurring forms that facilitate their recognition [50]. The repetition of certain general forms or relationships is characteristic of many objects. Texture is the arrangement and frequency of tonal change on an image. It gives a feeling of apparent roughness or smoothness to the interpreter. It is produced by an aggregation of unit features that may be too small to be discerned individually on the image. Shadows are important, affords an impression of the profile view of the object and subtle variations in terrain elevations. As a rule, images are more easily interpreted when shadows fall toward the observer. Site refers to topographic or geographic location. Association refers to the occurrence of certain features in relation to others [52] but not like pattern. However, collateral information and non-image information are required to assist in image the interpretation [50].

\section{Digital Image Processing}

The digital image usually contains of millions of discrete picture elements known as pixels. A digital image is not the same as a photograph, and only becomes a picture when converted from digital to analogue form on a display screen or in a photographic print. The minimum area covered by a pixel is known as resolution of the sensor, also known as ground resolution or spatial resolution. There is another resolution in remote sensing known as spectral resolution that defines which wavelength is used for the pixels of an array. A multispectral or multi-band image is made up of a series of digital images, one for each waveband images. The third resolution is the temporal resolution which indicates how often the sensor of a satellite acquire image over the terrain. Resolution in remote sensing data is very important to the users' objectives.

Digital image processing is the application of algorithms on digital images to perform, processing, analysis, and information extraction. Before extraction of information from earth surface data, as seen by the sensors in different wavelengths, need to be radiometrically and geometrically corrected. Digital image processing may involve numerous procedures including formatting and such corrections of data, digital enhancement to facilitate better visual interpretation, or even automated classification of targets and features entirely by computer. Modern archaeology increasingly crosses academic boundaries by combining different new methodologies in order to answer research questions about ancient cultures and their remains [53]. Thus, another advantage of modern-day technology may be taken that includes integration of data from multiple sources to extract better and/or more information, and even multitemporal, multi-resolution, multi-sensor or multi-data type may be integrated, depending on the objectives of the work.

\section{Remote Sensing Application in Archaeology}

Table 1: Commonly available some medium and high-resolution satellite data (Pan: panchromatic; VIS: visible light; NIR: near infrared;

MIR: mid infrared; TIR: thermal infrared; MS: multi-spectral).

\begin{tabular}{|c|c|c|}
\hline Sensors & Channels & $\begin{array}{c}\text { Spatial Resolution } \\
\mathbf{( m )}\end{array}$ \\
\hline Landsat 7 ETM+ & $\begin{array}{c}\text { (Pan, VIS, NIR, MIR, } \\
\text { TIR) }\end{array}$ & 15 Pan \\
\hline Landsat 8 & 9 (Pan, VIS, NIR, MIR) & 15 Pan \\
\hline Terra ASTER & $\begin{array}{c}14 \text { (VIS, NIR, MIR, } \\
\text { TIR) }\end{array}$ & 15 VIS, NIR \\
\hline SPOT 5 & 6 (Pan, VIS, NIR, MIR) & 5 Pan \\
\hline SPOT 6/7 & 5 (Pan, VIS, NIR) & 1.5 Pan \\
\hline IKONOS & 5 (Pan, VIS, NIR) & 1.0 Pan, 4 MS \\
\hline Quick Bird & 5 (Pan, VIS, NIR) & 0.61 Pan, 2.5 MS \\
\hline World View 2 & 9 (Pan, VIS, NIR) & 0.46 Pan, 2 MS \\
\hline World View 3 & 29 (Pan, VIS, NIR, & 0.31 Pan \\
\hline World View 4 & 5 (Pan, VIS, NIR) & 0.31 Pan \\
\hline Geo Eye 1 & 5 (Pan, VIS, NIR) & 0.41 Pan \\
\hline Pleiades 1A and 1B & 5 (Pan, VIS, NIR) & 0.5 Pan, 2 MS \\
\hline Rapid Eye & Pan, MS & 5 Pan, 5 MS \\
\hline Carto sat 2 & Pan & 0.8 Pan \\
\hline
\end{tabular}

The use of remote sensing has been applied to archaeological prospection and monitoring since the early days of aviation [53-55]. Lambers [56] found great potential for a truly semantic analysis of remote sensing data for archaeological purposes. 


\section{Global Journal of Archaeology \& Anthropology}

At present a vast array of active and passive remote sensing techniques are available. Since the launch in 1999 of IKONOS, the first civilian spaceborne Very High Resolution (VHR) multispectral sensor, archaeologists have access to relatively low cost VHR optical data over areas where airborne campaigns may be difficult or expensive to organize. However, many similar VHR multispectral spaceborne sensors are also available today, such as Quick Bird, WorldView-1 to 4, GeoEye-1, and Pleiades-1A and 1B. Some available satellites are given in Table 1.

\section{Survey for Archaeological Sites}

Visual image interpretation has proven particularly useful in locating sites whose existence lost to history [52]. Surface features include visible ruins, mounds, rock piles and various other surface markings. Subsurface archaeological features include buried ruins of buildings, ditches, canals, and roads. When such features are covered by agricultural fields or native vegetation, they may be revealed on aerial or satellite images by tonal anomalies resulting from subtle differences in soil moisture or crop growth. The traces of ancient human transformations of landscape create very subtle spatial features, namely surface anomalies that are only visible from a bird view. The characteristics of these archaeological features strongly depend on vegetation cover and phenology, pedology, soil types and topography, and named soil, shadow and crop marks $[57,58]$. Soil-marks can appear on bare soil as changes of tone/colour or texture. Shadow marks can be seen in presence of variations of micro-topographic relief visible by shadowing. Crop marks can be evident for vegetated areas, covered by crops or weeds. They can appear as differences in height or tone/colour in crops which are under stress due to lack of water or deficiencies in nutrients. There may have different in texture.

However, Chen [58] describe in detail the rational basis for archaeological marks. Past human occupation and activities have left traces and marks on landscape alterations and environmental changes that can be recognized even after centuries and millennia. For example, archaeological materials e.g. artifacts, bone, pottery or clusters of building materials would cause such changes. Erosional and depositional processes also contribute to changes. All these marks can be detected on remote sensing images, since the alteration they produce can be revealed by satellite sensors as they can influence spectral response and radar return. Bini [59] could identify different types of colour anomalies from SPOT 6 and SPOT 7 images as well as from Sentinel-2 image. Radar signal return from the object is dependent on radar look direction also. Modern day digital image processing technique can enhance the visibility. Micro-topographic relief variation, sometimes important in archaeology, produces shadows on optical images acquired under low angle sunlight condition. But in case of microwave images i.e. shadow producing mechanism is different, depends on angle of incidence. On Radar image subtle relief can provide shadows, significant in neotectonics and useful in terrain analysis. From high resolution satellite images construction of digital elevation model (DEM), such micro-relief can be identified [60]
Vegetation type and pattern on near-surface archaeological site would show different tone and texture from its surroundings on the image. These happen because compositions of the buried archaeological materials are different; this would have different water holding capacity. Thus, the vegetation gets different water and nutrient from underlying materials showing this difference on the image. There are two kinds of crop marks, including negative marks above wall foundations and positive marks [57] above the damp or nutritious soil of buried pits and ditches. The crop marks in SAR images are indicated by backscattering anomalies instead of the Near Infrared Red (NIR) spectral separability of optical remote sensing [58]. The occurrence of archaeological remains can change soil types and contents compared with their surroundings resulting in the well-known phenomenon of soil marks showing change in tone and texture in the absence of vegetation cover. Damp marks appear on bare ground because buried archaeological-remains can alter drainage capability and, in turn, water distribution. The detectability of damp marks is linked to soil type, climate and meteorological conditions.

Bangladesh examples: Examples from two archaeological sites/places may be cited here. Efforts have been taken to evaluate the visibility on remote sensing images for two large archaeological sites in Bangladesh, situated in two different geological environments. These sites/places are at Dharmapalgarh, Nilphamari and Wari-Bateshwar, Narshingdi. The first site is on Young Tista Alluvial Fan that contains Recent unconsolidated sediments and the site is younger than the later The second site is on the uplifted terrace containing Pleistocene oxidized soils and about $4^{\text {th }} \mathrm{BC}$ old.

The walls of the archaeological site at Dhamapalgarh, Nilphmari (Figure 1) are visible on CORONA satellite photograph, Landsat TM and Google images. On the CORONA satellite photograph acquired during late 1960s and Google image acquired in 2011 rampart of this fortified city of Dhormo Pal and structure of another nearby-site in Nilphamari district are easily identifiable (Figure 9). It is a rectangular structure (1mile (N-S) $\mathrm{x} 1 / 2$ mile (E-W)) [61], but its eastern wall has been eroded away by one of the paleo-courses of the Tista River. However, on the Landsat TM bands 3 and 4 north and west walls are identifiable, south wall is not visible; whereas the site is not visible on bands 1 and 2, this needs more study. Obviously, Landsat TM FCC shows the north and west walls clearly as white colour in the red coloured background. It is also noticeable the changes that took place during the 1960 s and 2010s period due to natural (vegetation and channel morphology) and anthropogenic (agriculture, settlements and road construction) activities. During a field visit, detection of the continuity of the walls was found not easy. This area experiences inundation from annual flooding that brings sediments, deposit on the plain. The area also experiences subsidence due to usual geologic processes. In the field visit to a nearby mound site an elderly local resident informed that the mound was at a higher elevation about 4550 years ago than that of today. Main anthropogenic activities 
include intense agriculture and reuse of the bricks for local purposes.

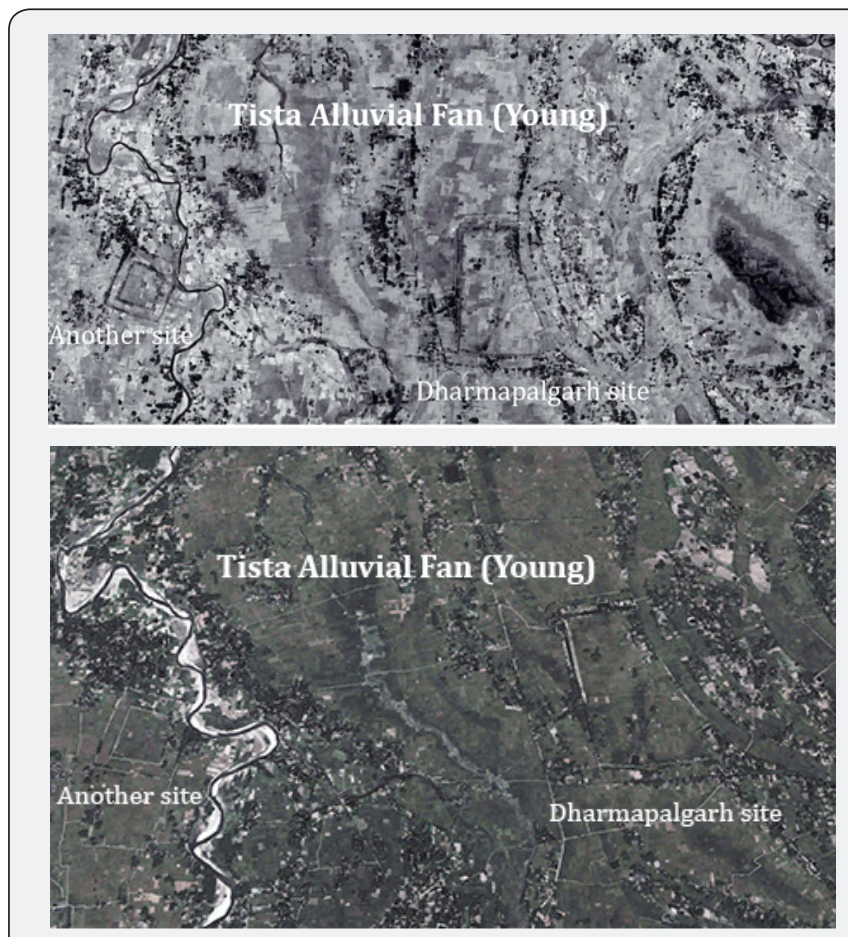

Figure 9: Archaeological sites at and near Dharmapalgarh, Nilphamari, Bangladesh clearly visible on CORONA satellite photograph (top) and Google Image (bottom). On photograph and image geomorphological features are identifiable.

The fort-city or urban centre of Wari-Bateshwar is enclosed with four mud ramparts in a $600 \mathrm{~m} \times 600 \mathrm{~m}$ area [13]. This site (Figure 10) is clearly visible on CORONA satellite photograph and Google images, from their shape, size and association. However, the site was not identifiable on Landsat TM image. This result is only from visual interpretation; enhancement in digital images may help in identification of such features. Due to the position of the site above flood level there is no or very little sedimentation. Little amount of sediments may come from surface erosion. Anthropogenic activities include cultivation of land, cutting red soil for building local mud-house, digging pit for dumping garbage etc. by local people. Luo [62] found GoogleEarth very high-resolution imagery to be powerful for a range of different archaeological and cultural heritage applications.

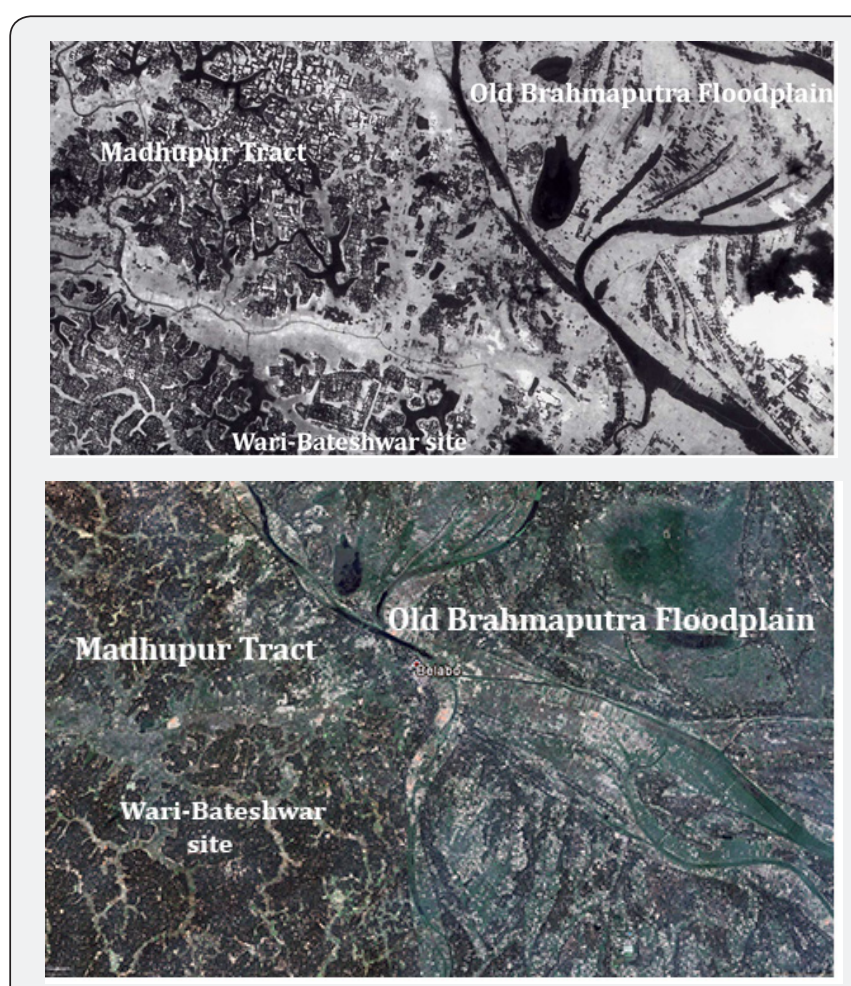

Figure 10: Archaeological site at Wari-Bateshwar, Narshingdi, Bangladesh clearly visible on CORONA satellite photograph (top) and Google Image (bottom). Geomorphological features of the both the landforms are clearly identifiable on photograph and image.
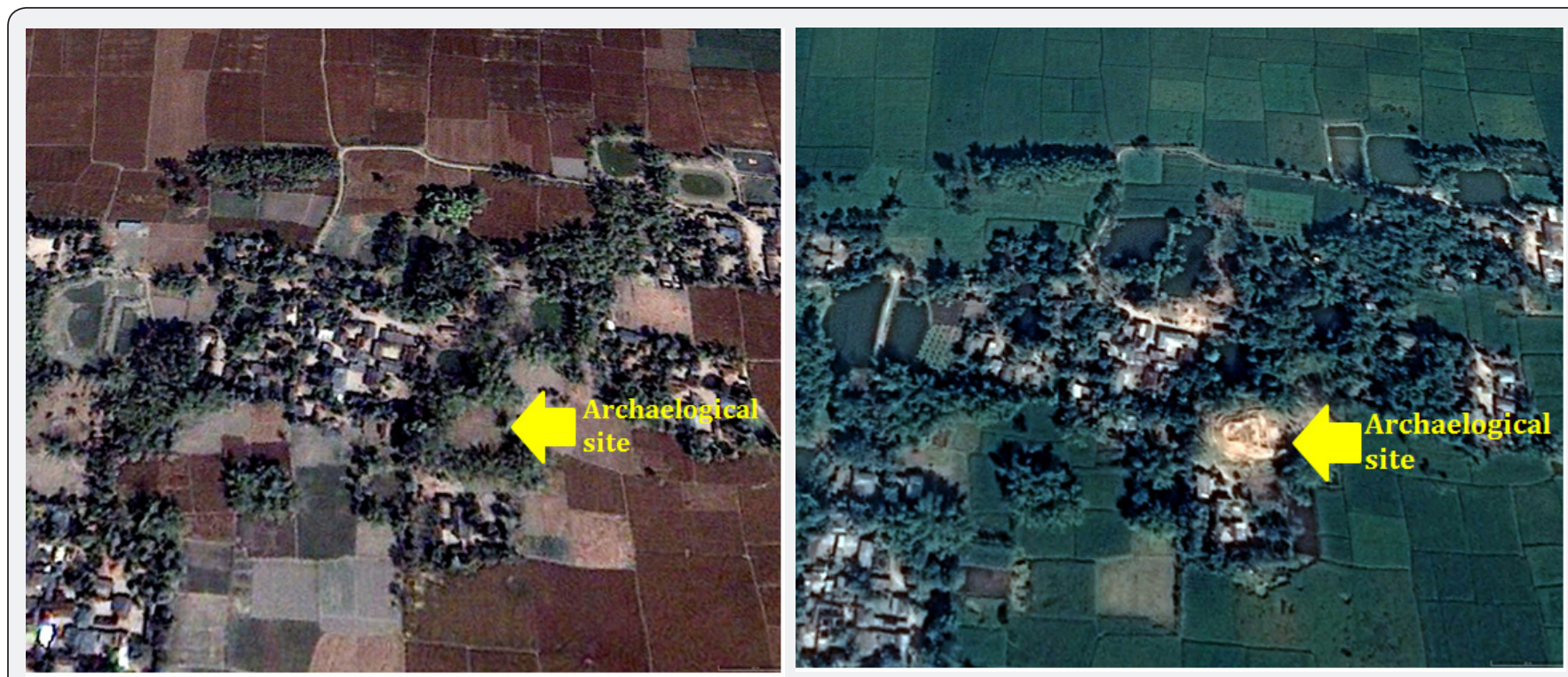

Figure 11: Archaeological site/place at Madhabgaon, Dinajpur, Bangladesh showing situations before (left) and after (right) excavations. 
Comparison of situations at two different times - before and after excavations at an archaeological site/place at Madhabgaon, Dinajpur district is shown in Figure 11. Geologically the site is on the Old Tista alluvial fan, surficial sediments are of early Holocene time. The image before excavation (left) shows only a round-shape land with smooth texture and light tone surrounded by vegetation, although no significant archaeological evidence is identifiable. But the image acquired after excavation (right) gives light tone with rough texture. Substantial changes on the site made during excavation give such changes in tone and texture.

\section{Geoarchaeology}

In geoarchaeology, primarily a subset of geosciences is considered [63] that include particularly geomorphology, sedimentology, pedology and stratigraphy. For geoarchaeological research in an alluvial terrain it is important to know the influence of internal (autogenic i.e. caused by infilling of sediments to storage site or sudden channel modification) and external (allogenic i.e. caused by alterations in catchment characteristics and tectonics) forces in channel change. But, changes in catchment characteristics and alteration of sediments in depositional site are related with climate change. Mehdi [64] concluded, based on the available data on sediments, that the buried channels, identified from Landsat ETM+ and SRTM and ASTER DEM data, at depths 6-13m were last active between 6 and 3 Ka B.P., when they supported the archaeological settlements along their banks. Ferentinos [65] opined that geological evidence for disappeared habitation sites can be identified from remote sensing.

Rivers and associated floodplain depositional environments are important in archaeology [66]; they served as notable significant loci for past occupations [67]. These dynamic landscapes exhibit a variety of local sedimentary environments [68] producing terraces, wealth of stratigraphic, paleoenvironmental and geoarchaeological information [67]. Alam \& Islam [69] successfully mapped the terraces on the Brahmaputra floodplain using SPOT Pan Imagery. Such information contributes to infer past conditions from floodplain sediments comes from the analysis of contemporary rivers and their sedimentation [68] i.e. the present is the key to the past. The utility of SAR remote sensing to detect the subsurface in sand covered areas has long been known $[70,71]$. Stewart [72] evaluated X-band SAR data and found to have limited capability for prospection of archaeological structures buried in sand covered areas. Its success depends also on the terrain condition, among other controlling factors.

In Bangladesh, SAR data have so far used in flood assessment $[73,74]$ using RADARSAT data and for measuring subsidence rate [48] in the delta using SAR interferometry (ALOS L-band InSAR). In geomorphological study, Alam $[75,76]$ could identify different features on RADARSAT (C-band) and JERS-1 (L-band) SAR images e. g, dry valleys (not buried) on the uplifted terrace and active channels but lithological discrimination was not possible. In another study, even geomorphological features were not identifiable [25]. Probably high moisture content, influences die-electric property of the materials hampers the process of image interpretation. As the terrain condition of Bangladesh is different from the above-mentioned examples [70,72], potentiality of available SAR images from RADARSAT and ERS (C-band) or JERS may be evaluated and same for the ground penetrating radar (GPR) dependency on water or moisture [66] among others.

Bangladesh examples: Earliest work among the above was done by [15] where he mapped drainages and landforms in the eastern part of Bangladesh from Landsat imagery and aerial photographs and described in detail about landform evolution. Bakr $[15,77]$ showed the relationship of archaeological sites of 8-10th century and landscape, how the uplift of the Early Recent Chandina Deltaic Plain including shifting of river courses badly affected the environment of the area. Akanda [78] studied satellite images to detect the nature of archaeological records in terms of geomorphology, geology, elementary pedology and stratigraphy of Wari-Bateshwar area in order to understand the influence of fluvial environmental variables on deposition and modification of archaeological records. They concluded that any archaeological inference on the area must be corroborated by the geoarchaeological evaluation.

Sen [79] successfully used, among others, satellite images to unfold the formative history of the floodplain and the lateral migration of rivers in the archaeological site of Somapura Mahavihara, Naogaon. Among other reasons, gradual migration of the main river in the area must have caused the settlement here to be abandoned. To understand the early Medieval settlement archaeology of the alluvial terrain of the northwestern part of Bangladesh Sen [80] carried out a detail study in a geo-spatial environment. He identified not only the various geomorphological features and potential archaeological features on the floodplain but also showed spatial patterns of archaeological places on satellite images. Paleo-channels of the Tista-Mahananda-Karatoya rivers have been identified $[81,82]$ from visual interpretation of aerial photographs and satellite images on the Tista Alluvial Fan. Their findings help in deciphering paleo-environment, river dynamics, anthropogenic impact on environment, paleoclimate condition etc, giving clues to the causes of migration and migration pattern of human settlements.

\section{Discussion and Conclusion}

As mentioned earlier that major part of Bangladesh is covered with Quaternary alluvial deposits, the region is tectonically influenced, and the sediments have experienced impacts of climate change as well. Such factors must have influenced the human settlements in the alluvial terrain, found ideal for past settlements [54]. Factors that influences changes in the landforms of the country at present time discussed in the previous paragraphs might have also influenced in the past resulting burial of human settlements or archaeological marks 
on the delta. The very widely accepted principle in geology 'present is the key to the past' may be applied in search of hidden archaeological sites using remote sensing. Advantage of medium and high spatial remote sensing data may be taken to locate archaeological site, and relatively low and medium resolution image data may be used in geoarchaeological study.

Depending on the purposes, selection of band is another important point needed to detect, identify and map the active and paleo-channels, and water bodies required for evaluating rate, pattern and style of channel migration. Smaller objects may be identifiable from their shape and association, however, may need to apply image enhancement techniques on the remote sensing data during digital image processing. High spatial resolution image e.g. Pleiades $(50 \mathrm{~cm})$, IKONOS, QuickBird $(60 \mathrm{~cm})$ etc. will help in identification of smaller size sites and objects. Moreover, DEM can be constructed using high resolution stereo-images that would give subtle micro-relief on plain lands, important clue for archaeological research. Due to several reasons' aerial photographs, advantage of having stereoscopic visibility capability, are not easily available. In that case high resolution satellite image may be used.

Geoarchaeological techniques and approaches are widely recognized as enabling syntheses of landscape development and the archaeological record [83]. But for Bangladesh, more works $[11,15,77-80,82]$ need to be done to examine and understand the changing human settlements with the changes of landforms in such alluvial terrain. Use of wide ranging remote sensing data from aerial photographs, CORONA satellite photographs, medium resolution satellite images (Landsat TM \& ETM+, SPOT, IRS) to high resolution (Lidar, Pleiades, RapidEye) and from optical to microwave (Radarsat, JERS and ERS) contributed much to geological, geomorphological, urban geological [84], environment, natural hazard assessment [50] etc. furnished with successful results in Bangladesh. But the relationship between SAR signal and terrain characteristics is yet to be well understood, important also for archaeological research. Because of its different geologic and geotectonic characteristics, identification of buried sites using SAR images is in doubt. Only the expert visual image interpreter can use SAR images for geoarchaeology. However, SAR look direction gives the advantage in locating linear features on the image. Anyway, research must be carried on for a better understanding of these relationships and identification capabilities.

CORONA satellite photographs provide information of the time prior to Landsat era. These photographs were acquired during 1960 and 1972, now become available for civilian use [50], with variable spatial resolution $(\sim 2-12 \mathrm{~m})$ and in black and white [59]. At that time, population of this country and population pressure on the land and environment, development activities were much less than those of today. The advantage of CORONA satellite photograph may be taken for archaeological research to see situation in a relatively less modified landform, favouring identification of archaeological marks. Significant development in remote sensing techniques have been made during the last few decades advantages of which should be taken to locate and identify buried features prior to excavation, and to understand the relationship between human settlements with their geological environments.

After an evaluation of archaeological works done using remote sensing data particularly in Bangladesh context application of this technology is in the initial stage and it has much potentiality. Depending on nature of problem selection of multi-spectral, multi-resolution or multi-temporal image will depend. In order to extract meaningful information, based about Bangladesh i.e. the intensively cultivated lands, huge anthropogenic influence on environment, vegetation cover, influence of geomorphic, geologic and tectonic processes, and climatic condition; appropriate image interpretation and digital image processing techniques should be performed. Successful extraction of relevant information can improve our level of understanding about our environment, which may need integration of data from different sources. Another important point is that an integrated approach of archaeologists, geologists and remote sensing experts would bring successful results to solve the archaeological problems.

\section{Acknowledgement}

Professor Sufi Mostafizur Rahman, Professor Syed Mohammad Kamrul Ahsan and Professor Swadhin Sen of Department of Archaeology, Jahangirnagar University kindly provided support to visit the archaeological sites in the central and fieldwork in the north-western parts of Bangladesh at various times. Discussions with them on various aspects of archaeology, human settlements and their relationship with landscape etc. enriched the author's level of understanding. Reshad Md. Ekram Ali of Geological Survey of Bangladesh kindly provided CORONA satellite photographs. All their supports are gratefully acknowledged. Finally, I would like to thank Nahid Arjuma Begum, my beloved wife, who rendered whole-hearted and continuous support to all my scientific and research works, especially more desirable in retired life.

\section{References}

1. Gamble C (2001) Archaeology: The Basics, Routledge, UK.

2. Greene K (2003) Archaeology: An Introduction, Routledge, UK.

3. Van Westen CJ (1994) Geographical information systems in landslide hazard zonation: a review with examples from the Andes of Colombia. In: Price MF, Heywood DI (Eds.) GIS Application for Mountain Areas, Taylor and Francis, UK, pp. 135-166.

4. Reimann KU (1993) Geology of Bangladesh, Gebruder Borntrger, Berlin.

5. Brammer H (1996) The Geography of the Soils of Bangladesh, University Press Ltd, Dhaka, Bangladesh.

6. Alam AKMK (2015) Current Status of Geological Remote Sensing in Bangladesh, Journal of Earth and Environmental Sciences (JEES), Faculty of Earth and Environmental Sciences, University of Dhaka, Bangladesh, 4: 71-80. 


\section{Global Journal of Archaeology \& Anthropology}

7. Rahman SM (2009) The Cultural Survey of Bangladesh. Asiatic Society of Bangladesh, Dhaka, Bangladesh.

8. Ahsan SMK (2009) Prehistoric Settlements, The Cultural Survey of Bangladesh. Asiatic Society of Bangladesh, Bangladesh.

9. Ahmed B (2009) Megalithic Culture, The Cultural Survey of Bangladesh, Asiatic Society of Bangladesh, Dhaka, Bangladesh.

10. Herz N, Garrison EG (1998) Geological Methods for Archaeology. Oxford University Press, Oxford, UK.

11. Islam MK, Hasan M, Majlis ABK, Alam AKMK (2006) Geoarchaeology of Wari-Bateshwar Area, Narshingdi District, Bangladesh Journal of Geology, Bangladesh, 25: 1-12.

12. Alam MK, Hassan AKMS, Khan MR, Whitney JW (1990) Geological Map of Bangladesh, Geological Survey of Bangladesh. Dhaka, Bangladesh.

13. Rahman SM (2017) Archaeological Heritage of Bangladesh. Journeyman Books Edition, Dhaka, Bangladesh.

14. Banglapedia (2012) www.en.banglapedia.org/index.php? Banglapedia: National Encyclopedia of Bangladesh.

15. Bakr MA (1977) Quaternary Geomorphic Evolution of the Brahmanbaria-Noakhali Area, Comilla and Noakhali Districts, Bangladesh. Records of the Geological Survey of Bangladesh, 1(2): $1-48$.

16. Alam AKMK (2001) Geomorphology and Neotectonics of Some Faults in Bangladesh, Bangladesh Geoscience Journal, 7: 51-62.

17. The Daily Star (2018) 1000-Year Old Buddhist City, Nateshwar can be world Heritage Site.

18. Prothom Alo (2018) Old Human Settlements in the Sundarbans (Sundarbone Prachin Manab Bashati).

19. Hanebuth TJJ, Kudrass HR, Linstadter J, Islam B, Zander AM (2013) Rapid Coastal Subsidence in the central Ganges-Brahmaputra Delta (Bangladesh) since the $17^{\text {th }}$ century deduced from submerged saltproducing kilns, Geology.

20. Das JD, Saraf AK, Jain AK (1995) Fault Tectonics of the Shillong Plateau and Adjoining Regions, North-east India Using Remote Sensing Data, International Journal of Remote Sensing, 16(9): 1633-1646.

21. Alam AKMK, Islam MB (2017) Recent changes in Jadukata fan (Bangladesh) in response to Holocene tectonics, Quaternary International, 462: 226-235.

22. Rajendran K, Parameswaran RM, Rajendran CP (2017) Seismotectonic perspectives on the Himalayan arc and contiguous areas: Inferences from past and recent earthquakes, Earth-Science Reviews, 173: 1-30.

23. Kayal JR (2010) Seismotectonics of Northeast India and Bangladesh Region: An Appraisal. In: Ahsan R, Islam MS, Shahriar A, Noor MA, AlHussaini TM (Eds.), Proceedings of the $3^{\text {rd }}$ International Earthquake Symposium, Dhaka, Bangladesh, p. 13-18.

24. Khan MR (2002) Plate Tectonics and Bangladesh, Journal of the Asiatic Society of Bangladesh, Golden Jubilee Issue, Dhaka, Bangladesh, 28(2): 39-62.

25. Alam AKMK (2017) Neotectonic Signatures from the Northern Bengal Basin in Bangladesh. Lambert Academic Publishers, Germany.

26. Khan FH (1991) Geology of Bangladesh, The University Press Limited, Dhaka, Bangladesh.

27. Johnson SJ, Alam AMN (1991) Sedimentation and tectonics of the Sylhet Trough, Bangladesh. Geological Society of America Bulletin, 103: 1513-1527.

28. Coleman JM (1969) Brahmaputra River: Channel Processes and Sedimentation, Sedimentary Geology, 3: 129-239.
29. Srivastava V, Mukul M, Mukul M (2017) Quaternary deformation in the Gorubathan recess: Insights on the structural and landscape evolution in the frontal Darjiling Himalaya. Quaternary International, 462: 138161.

30. Morgan JP, McIntire WG, (1959) Quaternary Geology of the Bengal Basin, East Pakistan and India, Bulletin of the Geological Society of America, 70: 319-342.

31. Alam MK (1988) Geology of Madhupur Tract and Its Adjoining Areas in Bangladesh. Records of the Geological Survey of Bangladesh, 5(3): 1-18.

32. Syvitski JPM, Kettner A, Overeem I, Hutton EWH, Hannon MT Brakenridge GR, Day J, Vorosmarty C, Saito Y, Giosan L, Nicholls R (2009) Sinking deltas due to human activities, Nature Geoscience, 2: 681-686.

33. Kuehl SA, Allison MA, Goodbred SL, Kudrass H (2005) The GangesBrahmaputra Delta, River Deltas-Concepts, Models, and Examples; SEPM (Society for Sedimentary Geology), 83: 413-434.

34. Brammer H (2012) The Physical Geography of Bangladesh. The University Press Ltd, Dhaka, Bangladesh.

35. Khandoker RA (1987) Origin of Elevated Barind-Madhupur Areas, Bengal Basin: Result of Neotectonic Activities, Bangladesh Journal of Geology, 6:1-9.

36. Hossain KM (1988) Earthquake Occurrences and Tectonics of Bangladesh. Bangladesh Journal of Geology, 7: 1-10.

37. Coates DA, Whitney JW, Alam AKMK, Huq MA (1988) Evidence of neotectonics activity of the Bengal Delta, Bangladesh, Geological Society of America, Abstract with Programmes, USA.

38. Coates DA, Alam AKMK (1990) The Mymensingh Terrace: Evidence of Holocene Deformation in the Delta of the Brahmaputra River, Central Bangladesh; Geological Society of America, Abstract with Programmes, USA.

39. Alam AKMK (1995) Neotectonic Evidences along the Eastern Margin of the Barind Tract, Bangladesh. Bangladesh Journal of Geology, 14: 25-31.

40. Alam AKMK, Coates DA, Mannan KH, Ahmed D, Hossain S (2008) Geology of Parts of Tangail and Mymensingh Districts, Bangladesh; Records of the Geological Survey of Bangladesh, 11(5): 1-43.

41. Rashid MB (2011) Geomorphic Evolution of the Barind Tract, Bangladesh, University of Rajshahi, Unpublished PhD Thesis.

42. Nandy DR (2001) Geodynamics of Northeastern India and adjoining Region, ACB Publication, Kolkata, India.

43. Karim MF, Mimura N (2008) Impacts of climate change and sealevel rise on cyclonic storm surge floods in Bangladesh. Global Environmental Change, 18: 490-500.

44. Alam AKMK (2014) Sikkim Earthquake 2011: Bangladesh Experience, In: Montomoli C (Eds.), Proceedings for $29^{\text {th }}$ Himalayan-KarakoramTibet Workshop, Lucca, Italy, Journal of Himalayan Earth Sciences.

45. Alam AKMK, Ahsan A (2016) Bangladesh's experience of the Nepal earthquake: A story of the impact on a seemingly unconnected region, In: Singh SP, Khanal SC, Joshi M (Eds.), Lessons from Nepal's Earthquake for the Indian Himalayas and the Gangetic Plains, Central Himalayan Environment Association (CHEA); Nainital, India, pp. 102-114.

46. Alam AKMK (2018) The 5.7 Dhalai (Tripura, India) 3 January 2017 Earthquake: Impacts in Bangladesh (Abs), ${ }^{\text {th }}$ Nepal Geological Congress (NGC-IX), Kathmandu, 19-21 November 2018, 57: 44.

47. Alam M (1996) Subsidence of the Ganges-Brahmaputra delta of Bangladesh and associated drainage, sedimentation, and salinity problem. In: Milliman JD, Haq BU (Eds.), Sea-level Rise and Coastal 


\section{Global Journal of Archaeology \& Anthropology}

Subsidence: Causes, Consequences, and Strategies. Kluwer Academic Publishers, Dordrecht.

48. Higgins SA, Overeem I, Steckler MS, Syvitski JPM, Seeber L, Akhter SH (2014) InSAR measurements of compaction and subsidence in the Ganges-Brahmaputra Delta. Bangladesh; Journal of Geophysical Research: Earth Surface, 119: 1768-1781.

49. BBS (Bangladesh Bureau of Statistics) (2018) Statistical Year Book Bangladesh 2017, Ministry of Planning, Government of the People's Republic of Bangladesh, Dhaka, Bangladesh.

50. Campbell JB, Wynne RH (2011) Introduction to Remote Sensing, The Guilford Press, New York, USA.

51. Bhatta B (2009) Remote Sensing and GIS. Oxford University Press, Oxford, UK

52. Lillesand TM, Kiefer RW, Chipman JW (2004) Remote Sensing and Image Interpretation.

53. Parcak S (2009) Satellite Remote Sensing for Archaeology. Routledge Press: New York, NY, USA.

54. Siart C, Forbriger M, Bubenzer O (2018) Digital Geoarchaeology: Bridging the Gap Between Archaeology, Geosciences and Computer Sciences. In: Siart C, Forbriger M, Bubenzer O (Eds.), Digital Geoarchaeology. Natural Science in Archaeology, Springer, p. 1-7.

55. Wilson DR (2000) Air Photo Interpretation for Archaeologists; Tempus Publishing: Stroud, UK.

56. Lambers K (2018) Airborne and Spaceborne Remote Sensing and Digital Image Analysis in Archaeology. In: Siart C, Forbriger M, Bubenzer O (Eds.), Digital Geoarchaeology, Natural Science in Archaeology, Springer, pp. 109-121.

57. Lasaponara R, Masini N (2012) Remote Sensing in Archaeology: From Visual Data Interpretation to Digital Data Manipulation. In: Lasaponara R, Masini N (Eds.), Satellite Remote Sensing--A New Tool for Archaeology, Springer, p. 3-16.

58. Chen F, Masini N, Yang R, Milillo P, Feng D, et al. (2015) A Space View of Radar Archaeological Marks: First Applications of COSMO-SkyMed X-Band Data, Remote Sensing, 7: 24-50.

59. Bini M, Isola I, Zanchetta G, Ribolini A, Ciampalini A, et al. (2018) Identification of Leveled Archeological Mounds (Höyük) in the Alluvia Plain of the Ceyhan River (Southern Turkey) by Satellite RemoteSensing Analyses, pp. 241.

60. Ahsan A, Kali E, Coudurier-Curveur A, Woerd J Vander, Tapponnier P, et al. (2015) Active Faulting in Raghunandan Anticline, NE Bengal Basin, Implications for Future Earthquake Hazards, Americal Geophysica Union (AGU) Fall Meeting, San Francisco, USA.

61. Montgomery M (1838) The History, Antiquities, Topography, and Statistics of Eastern India (Ronggopoor District), W. H. Allen and Co, Leadenhall Street, London, UK, 3(II): 351-596.

62. Luo L, Wang X, Guo H, Lasaponara R, Shi P, et al. (2018) Google Earth as a Powerful Tool for Archaeological and Cultural Heritage Applications: A Review. Remote Sensing, 10: 1558.

63. Pollard AM (1999) Geoarchaeology: exploration, environments resources; Geological Society, London, UK, pp. 165

64. Mehdi SM, Pant NC, Saini HS, Mujtaba SAI, Pande P (2016) Identification of palaeochannel configuration in the Saraswati River basin in parts of Haryana and Rajasthan. India, through digital remote sensing and GIS, Episodes, 39(1): 29-38.

65. Ferentinos G, Papatheodorou G, Geraga M, Christodoulou D, Fakiris E, et al. (2015) The Disappearance of Helike-Classical Greece-New Remote Sensing and Geological Evidence. Remote Sensing, 7: 1263 1278.
66. Conyers LB (2016) Ground Penetrating Radar for Geoarchaeology.

67. Goldberg P, Macphail RI (2006) Practical and Theoretical Geoarchaeology. Blackwell Publishing, USA

68. Brown AG (1997) Alluvial Geoarchaeology. Cambridge University Press, Cambridge, UK

69. Alam AKMK, Islam MB (2011) Geomorphological Mapping of Holocene Terraces Using SPOT Image on the Brahmaputra Floodplain in Bangladesh. Bangladesh Journal of Geology, 29(30): 41-48.

70. Elachi C, Roth LE, Schaber GG (1984) Spaceborne radar subsurface imaging in hyperarid regions. IEEE Transactions on Geoscience and Remote Sensing, 22: 383-388.

71. Roth LE, Elachi C (1975) Coherent electromagnetic losses by scattering from volume inhomogeneities. IEEE Trans. Antennas Propag. 23: 674675

72. Stewart C, Oren ED, Cohen-Sasson E (2018) Satellite Remote Sensing Analysis of the Qasrawet Archaeological Site in North Sinai. Remote Sensing, 10: 1090

73. Hoque R, Nakayama D, Matsuyama H, Matsumoto J (2011) Flood monitoring, mapping and assessing capabilities using RADARSAT remote sensing. GIS and ground data of Bangladesh, Natural Hazards, 57(2): 525-548.

74. Chowdhury EH, Hassan QK (2017) Use of remote sensing data in comprehending an extremely unusual flooding event over southwest Bangladesh, Natural Hazards, 88: 1805-1823.

75. Alam AKMK (1997) Synthetic Aperture Radar Image Interpretation of Karnaphuly River Area, Bangladesh. Journal of Nepal Geological Society, p. 16

76. Alam AKMK (2001) Geological Observations from Satellite Radar Images: Useful for Coastal Zone Studies. In: Alam AKMK, Islam MK (Eds.), Proceedings of the International Seminar on Quaternary Development and Coastal Hydrodynamics of the Ganges Delta in Bangladesh. Geological Survey of Bangladesh; Dhaka, Bangladesh, p. 49-55.

77. Bakr MA (1971) Human settlement in the Bengal Basin in relation to geologic setting, Journal of Asiatic Society of Pakistan, 16 (1): 89-99.

78. Akanda MKH, Ahsan SMK, Sen S (2005) Nature of Archaeological Records on Floodplain: A Geoarchaeological Interpretation of WariBateshwar. Bangladesh, Pratnatattva, 11: 75-86.

79. Sen S, Rahman AKMS, Ahsan SMK (2014) Crossing the Boundaries of the Archaeology of Somapura Mahavihara: Alternative Approaches and Propositions. Pratnatattva, 20: 49-79.

80. Sen S (2017) Landscape Contexts of the Early Mediaeval Settlements in Varendri/Gauda: An Outline based on Total Surveying and Excavations in Dinajpur-Joypurhat Districts. Bangladesh, Pratna Samiksha, Kolkata: Centre for Archaeological Studies \& Training, Eastern India, 8: 59-109.

81. Khan SI, Williams van S, Das SK, Hassan KZ (1990) Geology of Panchgarh District, Rajshahi Division, Bangladesh. Records of the Geological Survey of Bangladesh, 6: 2 .

82. Alam AKMK, Chakraborty T, Sen S (2017) Preliminary Results of a Comprehensive Geoarchaeological Study in the Distal Part of the Tista Megafan, Bangladesh (Abs), Abstract Volume, An International Conference on Early Medieval/Medieval in Bengal: Transdisciplinary Perspectives in Archaeology with Special Reference to Bangladesh, Department of Archaeology, Jahangirnagar University, Bangladesh.

83. Passmore DG, Waddington C, Schriek T vander, Davis B, Tetlow E, et al. (2011) Geoarchaeology andarchaeological landscapes in the Till River valley, northern England. In: Brown AG, Basell LS, Butzer KW (Eds.), Geoarchaeology, Climate Change, and Sustainability; Geological Society of America Special Paper 476: 117-133. 
84. GSB (Geological Survey of Bangladesh), BGR (Federal Institute for Geoscience and Natural Resources) (2009) Assessment of Hazards in Purbachal Area. Bangladesh Using High-Resolution Lidar Data and
Aerial Photograph, International Conference on Geoscience for Global Development, Dhaka, Bangladesh.

\section{Your next submission with Juniper Publishers will reach you the below assets}

- Quality Editorial service

- Swift Peer Review

- Reprints availability

- E-prints Service

- Manuscript Podcast for convenient understanding

- Global attainment for your research

- Manuscript accessibility in different formats

( Pdf, E-pub, Full Text, Audio)

- Unceasing customer service

Track the below URL for one-step submission https://juniperpublishers.com/online-submission.php 